\title{
A NEW SPECIES OF THE GENUS YURIRIA JORDAN \& EVERMANN, 1896 (ACTINOPTERYGII, CYPRINIDAE) FROM THE AMECA BASIN OF THE CENTRAL MEXICAN PLATEAU
}

\author{
O. Domínguez-Domínguez ${ }^{1,3, *}$, A. Pompa-Domínguez ${ }^{1} \&$ I. Doadrio ${ }^{2}$
}

\begin{abstract}
A new cyprinid species is described based on morfometric, meristic and genetic characters. The new species identified, Yuriria amatlana sp. nov., inhabits the high Ameca Basin in the central plateau of Mexico. This Mexican minnow differs from Yuriria alta and Yuriria chapalae in terms of the following characters: (50-52) 53-54 pored lateralline scales; 10 upper transverse-line scales, 5-6 lower transverse-line scales and 8-10 gill rakers. Body coloration is light yellowish-brown. Compared to Yuriria alta and Yuriria chapalae, the new species has a less conspicuous dark grey band running from the start of the dorsal fin to the head. Cytochrome $b$ gene sequences differ from those of Yuriria alta and Yuriria chapalae in terms of 29 fixed nucleotide positions (molecular autopomorphies). Calculated genetic divergences for the cytochrome $b$ gene were: ' $\mathrm{D}_{\mathrm{HKY}}=3.8$ (3.2-4.4\%) between Yuriria amatlana sp. nov. and $Y$. alta; ${ }^{\prime} \mathrm{D}_{\mathrm{HKY}}=5(4.8-5.2 \%)$ between $Y$. amatlana sp. nov and $Y$. chapalae; and ${ }^{\prime} \mathrm{D}_{\mathrm{HKY}}=2.6(2.1-3.3 \%)$ between $Y$. chapalae and Y. alta.
\end{abstract}

Key words: Mexico Central Plateau, Yuriria amatlana sp. nov., Cyprinidae, Cypriniformes, Ameca Basin, Taxonomy, Conservation, Endangered species.

\section{RESUMEN}

Una nueva especie del género Yuriria Jordan \& Evermann, 1896 (Actinopterygii, Cyprinidae) de la cuenca del río Ameca en la Mesa Central Mexicana

Se describe una nueva especie, Yuriria amatlana sp. nov., en base a caracteres morfométricos, merísticos y genéticos. La nueva especie proviene de la parte alta de la cuenca del río Ameca en la Meseta Central de México. Esta especie se diferencia de Yuriria alta y Yuriria chapalae por una combinación de los siguientes caracteres: (50-52) 53-54 escamas en una serie longitudinal, 10 escamas en una serie transversal por encima de la línea lateral y 5-6 escamas por debajo de la línea lateral y 8-10 branquiespinas. El color del cuerpo es amarillo-marrón claro. La nueva especie tiene una banda gris oscura menos

Laboratorio de Biología Acuática, Facultad de Biología, Universidad Michoacana de San Nicolás de Hidalgo, Morelia, Michoacán, Mexico. odoming@jupiter.umich.mx

2 Departamento de Biodiversidad y Biología Evolutiva, Museo Nacional de Ciencias Naturales, Madrid, Spain. mcnd147@mmcn.scic.es

3 Posgraduate in Marine Sciences and Limnology, ICMyL, Universidad Nacional Autónoma de México, Mexico, D. F.

* Author to whom correspondence should be addressed. Tel.: +52(443)3145030; fax: +52(443) 3167412; email: odoming@jupiter.umich.mx 
marcada en el cuerpo desde el comienzo de la aleta dorsal hacia la cabeza con respecto a Yuriria alta y Yuriria chapalae. La nueva especie se diferencia de Yuriria alta y Yuriria chapalae en 29 posiciones nucleotídicas fijadas (autopomorfias moleculares) para el citocromo $b$. La divergencia genética entre Yuriria alta y Yuriria amatlana sp. nov. para el citocromo $b$ fue de ${ }^{~} \mathrm{D}_{\mathrm{HKY}}=3.8$ (3.2-4.4\%); entre $Y$. amatlana sp. nov. y $Y$. chapalae fue ${ }^{`} \mathrm{D}_{\mathrm{HKY}}=5(4.8-5.2 \%)$ y entre $Y$. chapalae y $Y$. alta fue ${ }^{`} \mathrm{D}_{\mathrm{HKY}}=2.6(2.1-3.3 \%)$.

Palabras clave: Mesa Central Mexicana, Yuriria amatlana sp. nov., Cyprinidae, Cypriniformes, Cuenca del Ameca, Taxonomía, Conservación, Especie en peligro.

\section{Introduction}

Along with Algansea Girard, 1856 and Notropis Rafinesque, 1818, Yuriria completes the three cyprinid genera that characterize the endemic cyprinid fauna of Central Mexico. Phylogenetic relationships between the three genera are currently unresolved owing to their extensive genetic and morphologic differentiation. Several authors have assigned Yuriria to different clades within the Phoxinini cyprinids (see Chernoff \& Miller, 1986; Mayden, 1989; Mayden, 1991; Schönhuth \& Doadrio, 2003). Mayden's (1989) results show Yuriria in a polytomy forming part of a large clade supported by a single synapomorphy, an opening in the posterior myodome (OPM). Mayden's OPM clade contained 22 genera formed primarily by eastern North American cyprinids (including Notropis and Hybopsis Agassiz, 1854), but also included Agosia Girard, 1856, Oregonichthys Hubbs in Schultz, 1929, Richardsonius Girard, 1856 and Yuriria, genera typically considered part of the western North American freshwater fish fauna (Uyeno, 1961). Based also on osteological and external characters, Coburn and Cavender (1992) argued for the dismemberment of Mayden's OPM clade and reassigned its members to all three major clades of North American phoxinins that they recognized (a shiner clade sister to a chub clade, plus a "western" clade), and redescribed the genus Yuriria as a large polytomy at the base of the 'western' clade of North American cyprinids comprised of another 20 genera. In a recent study, Schönhuth and Doadrio (2003) based on molecular characters suggested a close relationship between the genus Yuriria and the genus Notropis of Central Mexico, and ascribed Yuriria to a sister clade of the Notropis calientis Jordan \& Snyder, 1899 group. Adopting a conservative criterion and pending a more extensive taxonomic revision, they proposed changing the taxonomic name Yuriria alta (Jordan, 1880) to Notropis altus. In a recent taxonomic revision of the freshwater fish of Central Mexico (Miller et al. 2005), different characters of the dorsal, pectoral and pelvic fins (position and size) are used as a taxonomic criterion to differentiate the genus Yuriria from other cyprinid genera. Within the Yuriria, two species have been described: Yuriria alta and Yuriria chapalae (Jordan \& Snyder, 1899). However, more recent revisions have interpreted $Y$. chapalae as a junior synonyn of $Y$. alta (see Gilbert, 1998).

The genus Yuriria is widely distributed across the Mesa Central of Mexico, occurring in the Cuitzeo, Zacapu and Chapala lakes, rivers of the LermaSantiago drainage basin, and the headwaters of the Ameca and Panuco river basins (Miller \& Smith, 1986; Espinosa et al., 1993; Lyons et al., 1998, 2000; Mercado-Silva et al., 2002; Miller et al., 2005). The population from the Ameca river basin, designated as Yuriria alta, was identified as an undescribed form of Yuriria by Miller and Smith (1986) and Espinosa et al. (1993). The purpose of the present study is to characterize genetically and morphologically the Yuriria populations of Central Mexico including descriptions of undescribed forms.

\section{Materials and Methods}

The specimens described herein were collected using hand and seine nets and by electrofishing. All the specimens sampled were preserved in $70 \%$ ethanol. Voucher specimens are housed at the Universidad Michoacana de San Nicolás de Hidalgo (CPUM), México. Universidad Nacional Autónoma de México (IBUNAM) and the Museo Nacional de Ciencias Naturales de Madrid (MNCN).

\section{MORPHOLOGICAL ANALYSIS}

The description of the new species is based on morphological analyses of the comparative material listed in the species description (Table 1).

No specimens were collected from the type locality of Yuriria alta (Lake Tupátaro, Guanajuato), where the species is supposed to be locally extinct, due to complete desiccation of the lake. The population examined here was obtained from the Laja River, which forms part of the same drainage and is also 
Table 1.- Localities and specimen numbers of the Yuriria populations used in morphometric, meristic and genetic analyses.

Tabla 1.- Localidades y número de individuos de las poblaciones de Yuriria usados en los análisis morfométricos, merísticos y genéticos.

\begin{tabular}{lllccc}
\hline & Species and populations & & Morphometrics & Meristics & Genetics \\
\hline Species & Locality & Basin & & & \\
\hline Y. alta & 1.- La Mintzita Spring & Cuitzeo Lake & 0 & 0 & $1^{*}$ \\
& 2.- Zacapu Lake & Zacapu Lake & 30 & 30 & $1^{*}$ \\
& 3.- Angulo River & Zacapu Lake & 0 & 0 & $1^{*}$ \\
& 4.- Laja River & Middle Lerma River & 30 & 30 & $1^{*}$ \\
& 5.- Ceja Dam & Middle Lerma River & 0 & 0 & 1 \\
& 6.- Duero River & Lower Lerma River & 0 & 0 & 1 \\
& 7.- Juchipila River & Santiago River & 0 & 0 & 1 \\
& 8.- Calvillo River & Santiago River & 0 & 0 & 1 \\
Y. cahapalae & 9.- Verde River & Santiago River & 0 & 0 & 1 \\
Y. amatlana & 10.- Guaracha Dam & Chapala Lake & 25 & 25 & 1 \\
\hline
\end{tabular}

*Sequences obtained from Genbank.

geographically close to the type locality. Measurements were performed following Doadrio et al. (2002). Nineteen morphometric parameters were measured using the computer program ImageTool 3.00 and six meristic variables were counted with the help of a stereoscopic microscope. The following abbreviations were used for morphometric and meristic characters: SL, standard length; HL, head length; PrOL, preorbital length; InOW, interorbital width; PoOL, postorbital length; Hh, head height; PrP prepectoral distance; $\operatorname{PrD}$, predorsal distance; $\mathrm{PrV}$, preventral distance; PrA, preanal distance; DFL dorsal fin length; PFL, pectoral fin length; PvFL, pelvic fin length; AFL, anal fin length; EALP, end of the anal fin-lower extreme of caudal peduncle distance; EDUP, end of dorsal fin-upper extreme of caudal peduncle distance; $\mathrm{BD}$, body depth; BLD, body least depth; DAOD, dorsal origin to anal origin fin distance. Abbreviations for the meristic characters are: $\mathrm{D}$, dorsal fin rays; Pv, pelvic fin rays; A, anal fin rays; GR, gill rakers; PLS, pored lateral-line scales; UTS, upper transverse scales, LTS lower transverse scales.

To identify the variables contributing most to the differences between the four populations sampled, principal component analyses (PCA) were performed on the meristic and morphometric data collected from all the specimens examined. The PCA results for the morphometric data (not shown) indicated that all weighted characters on the first principal component (PC I) showed the same sign and were of similar magnitude, suggesting that this axis represents general size-related variation
(Jolicoeur \& Mosimann, 1960; Humphries et al., 1981; Bookstein et al., 1985). To evaluate size-free shape differences between populations, Burnaby's method was used to correct for size effects (Burnaby, 1966; Rohlf \& Bookstein, 1987; Doadrio et al., 2002). All analyses were performed using the corrected matrix. A second PCA was conducted using a covariance matrix for morphometric characters and a correlation matrix for meristic characters. All analyses were performed using the statistics packages NTSYS v. 2.1 (Rohlf, 2000) and PAST v. 1.31. Morphometric and meristic characters were analysed independently.

\section{GENETIC ANALYSIS}

Four cytochrome $b$ gene sequences for Yuriria (AF469160-AF469163), one for Notropis calientis (AF469141) and one for Notropis sallaei (AF469 135) were obtained from GenBank. A further 8 specimens (including the new species) were collected from drainages covering the entire distribution range of the genus Yuriria (Table 1 and Fig. 1). The cytochrome $b$ gene sequences for these 8 specimens were obtained as follows: total DNA was isolated from tissues according to standard proteinase $\mathrm{K}$ and phenol/chloroform extraction procedures (Sambrook et al., 1989). Two overlapping fragments of the cytochrome $b$ gene $(1140 \mathrm{bp})$ were amplified by polymerase chain reaction (PCR). The primers used for cytochrome $b$ in all samples were those described in Zardoya and Doadrio, (1998). Amplification involved an initial denaturation step 


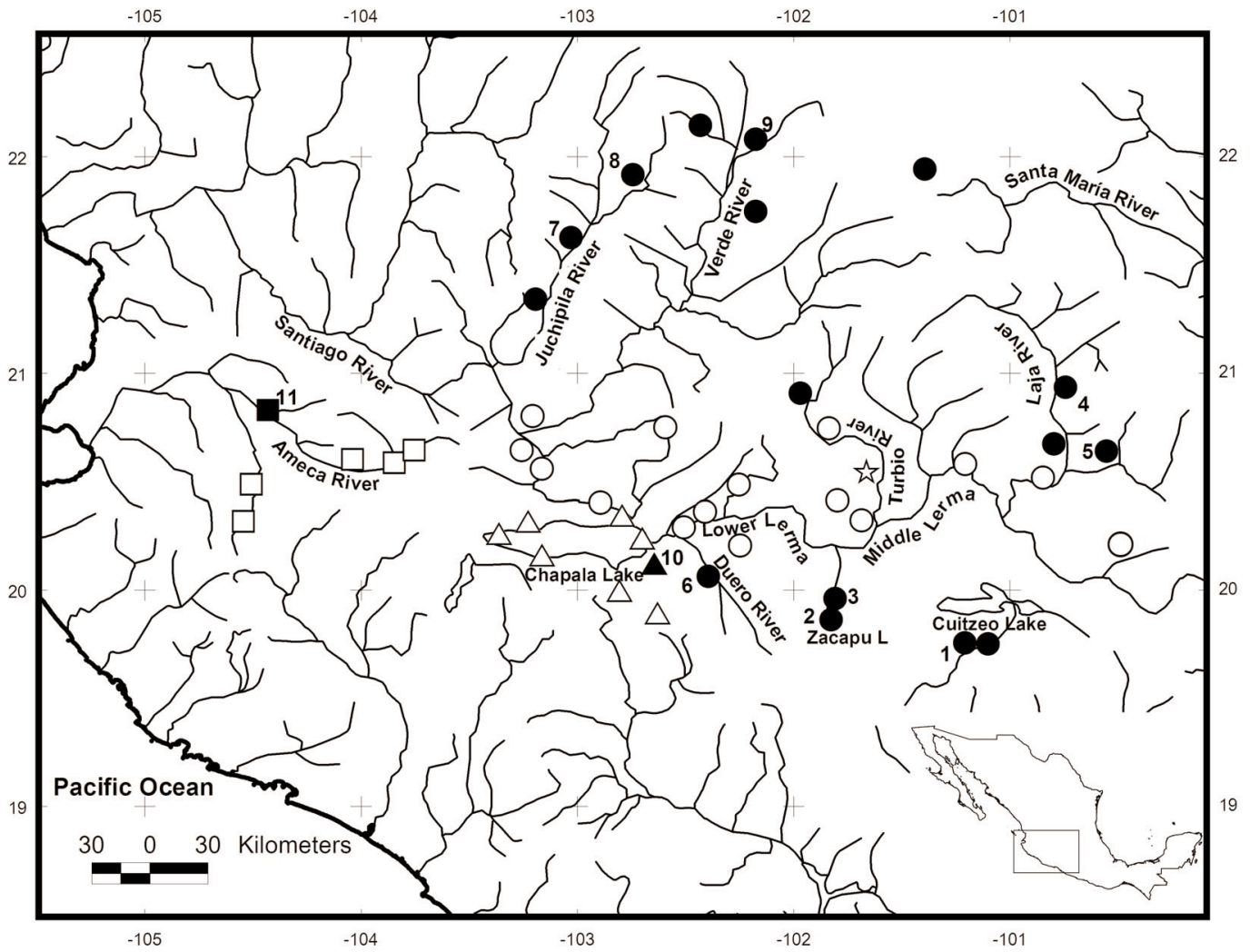

Fig. 1.- Distribution of Yuriria alta (circles), Yuriria chapalae (triangles) and Yuriria amatlana sp. nov. (squares). Star correspond to the Type locality of Yuriria alta (Lake Tupátaro). Open symbols correspond to historical occurrence points from which the species has not been collected in the last 5 years. Solid symbols represents sites from which the species has been collected in the last 5 years. Numbers correspond to the localities shown in Table 1.

Fig. 1.- Distribución de Yuriria alta (círculos), Yuriria chapalae (triangulos) y Yuriria amatlana sp. nov. (cuadrados). La estrellas corresponde a la Localidad Tipo de Yuriria alta (Lago Tupátaro). Símbolos vacíos corresponen a las localidades históricas donde la especie no ha sido localizada en los últimos 5 años. Símbolos llenos corresponden a localidades donde la especie ha sido colectada en los últimos 5 años. Números corresponden a las localidades señaladas en la Tabla 1.

at $94^{\circ} \mathrm{C}$ for $2 \mathrm{~min}$, followed by 35 cycles as follows: denaturation at $94^{\circ} \mathrm{C}(1 \mathrm{~min})$, annealing at $48^{\circ} \mathrm{C}(1 \mathrm{~min})$, and extension at $72^{\circ} \mathrm{C}(1.45 \mathrm{~min})$, with a final extension of $7 \mathrm{~min}$ at $72^{\circ} \mathrm{C}$. PCR were prepared in $25 \mu 1$ reaction containing final concentrations of $0.4 \mu \mathrm{M}$ of each primer, $0.2 \mathrm{mM}$ of each dNTP, $1.5 \mathrm{mM} \mathrm{MgCl}_{2}$, and $1 \mathrm{U}$ of Taq DNA polymerase (Biotools). PCR products were checked on $1.5 \%$ agarose gels, and cloned using the pGEM-T vector (Promega) into Escherichia coli JM109. Positive clones were sequenced using the FS-Taq Dye Deoxy Terminator cycle-sequencing kit (Applied Biosystems). The DNA sequences of both strands were determined using M13 universal (forward and reverse) sequencing primers. All samples were sequenced on an Applied Biosystems 3700 DNA sequencer following the manufacturer's instructions. Chroma-tograms and alignments were checked by visual inspection. We used Modeltest 3.7 (Posadas \& Crandall, 1998) to find the best evolutionary model that fit our data. The aligned data were analysed using the Bayesian inference method with the program Mr. Bayes 3.1.1 (Hueselsenbeck \& Ronquist, 2001) by simulating a Markov chain for 1,000,000 cycles. Based on the HKY model obtained by Modeltest, genetic distances $\left(\mathrm{D}_{\mathrm{HKY}}\right)$ between species were obtaining using the program Sequencer 6.1.0 (written by B. Kessing and available at http://nmg.si.edu/). Pairwise genetic distances were also obtained for each pair of populations 
using HKY distances as implemented in PAUP 4.0b10 (Swofford, 2002).

\section{Yuriria amatlana sp. nov.}

(Fig. 2A, Table 2)

Holotype. (Table 2, Fig. 2A) CPUM-1631, 58.62 mm SL. Río Chiquito, Ixtlan del Río, Amatlan de Cañas, Nayarit, Mexico. Geographic coordinates: latitude $20^{\circ} 48^{\prime} 2.1^{\prime \prime} \mathrm{N}$, longitude $104^{\circ} 25^{\prime} 37.1^{\prime \prime} \mathrm{W}$. Coll. R. Pérez-Rodríguez and R. Rosas-Valdez, 9 June 2005.

Paratypes. CPUM-1610-1630, 21 individuals; IBUNAM-P 14437, 5 individuals and MNCN259039-41, 3 individuals. Same data as for the holotype.

COMPARATIVE MATERIAL. Yuriria amatlana sp. nov. 22 specimens CPUM-1610-1630 and 1631, 5 specimens IBUNAM-P 14437 and 3 specimens MNCN259039-41 (Río Chiquito de Amatlan, Ixtaln del Río, Amatlan de Cañas, Ameca River Drainage, Nayarit); Yuriria chapalae 20 specimens CPUM-1595-1614 and 5 specimens IBUNAM-P14493 (Guaracha Dam, near San António Guaracha, Chapala Lake Drainage, Michoacan); Yuriria alta 30 specimens MNCN208.235 (Tributary of la Laja River, Balneario de Xote, near San Miguel de Allende, Guanajuato); and Yuriria alta 30 specimens MNCN-208.870 and MNCN-208.885 (Outflow of Zacapu Lake, near Panindicuaro, Michoacan) (Table 1).

DiAgNosis. Yuriria amatlana sp. nov. differs from its sister species, $Y$. alta and $Y$. chapalae, according to the following set of characters: 9 , rarely 10 (mean $=$ $9.36, \mathrm{SD}=0.49)$ branched rays on the pelvic fin (vs. 10, rarely 8-9 or 11 in $Y$. chapalae and 8, rarely 7 in Y. alta); (5052) $53-54,($ mean $=52.36, \mathrm{SD}=1.39)$ pored lateralline scales [vs. (48-50) 51 in $Y$. chapalae and (47-49) 50, (51) in Y. alta], and 10 scales in a transverse series up to the lateral line (vs. 9, rarely 8 in $Y$. chapalae and Y. alta) (Table 3). Body coloring light yellowish-brown (vs. yellow to golden coloration in Notropis amecae males). Dark grey band running from the start of the dorsal fin to the head less conspicuous than that observed for Y. alta and Y. chapalae (Fig. 2). Thirty-three fixed nucleotide positions, or autopomorphic characters, in the cytochrome $b$ sequence with respect to its sister species Y. alta and Y. chapalae (Table 4). Genetic divergences for the cytochrome $b$ gene ${ }^{\prime} \mathrm{D}_{\mathrm{HKY}}=3.8 \%$ (range $3.2 \%$ to $4.4 \%$ ) between Yuriria amatlana and Y. alta; ${ }^{\prime} \mathrm{D}_{\mathrm{HKY}}=5 \%$ (range $4.8 \%$ to $5.2 \%$ ) between $Y$. amatlana and $Y$. chapalae; and ${ }^{\prime} \mathrm{D}_{\mathrm{HKY}}=$ $2.6 \%$ (range $2.1 \%$ to $3.3 \%$ ) between $Y$. chapalae
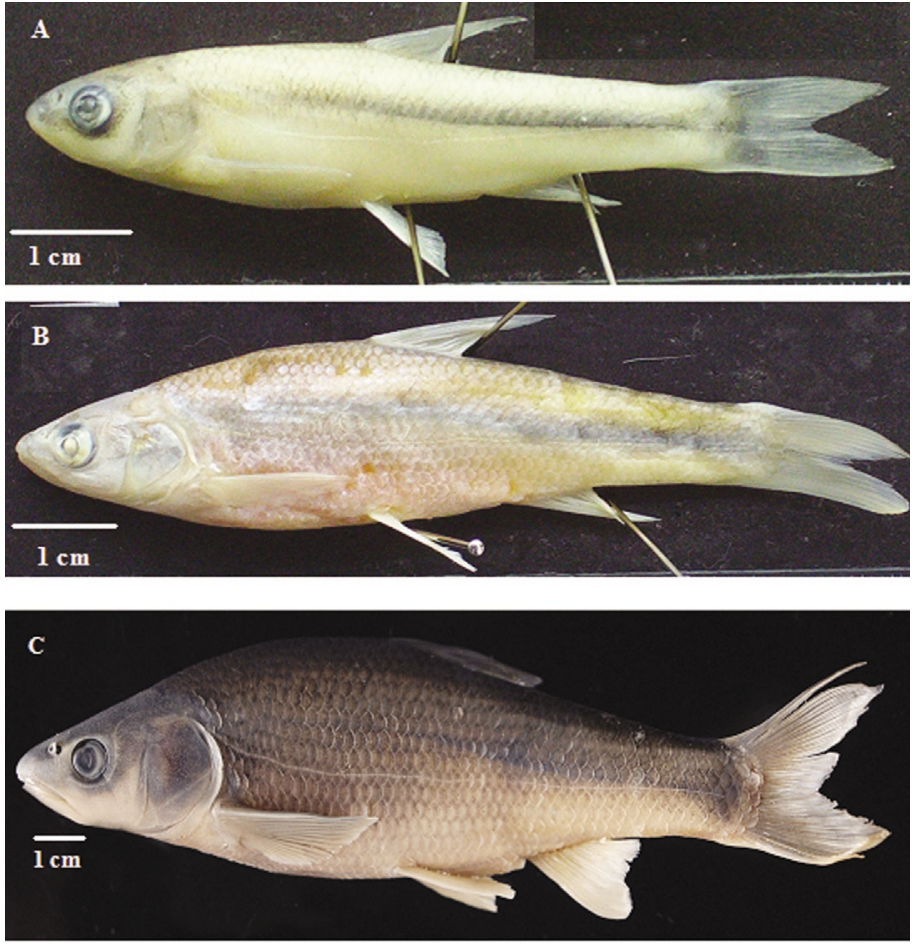

Fig. 2.-A) Yuriria amatlana sp. nov. Holotype CPUM-1630 from the Amatlan de Cañas population, Ameca River Basin, B) Y. chapalae from the Guaracha Dam population, Chapala Lake Basin, and C) Y. alta from the Zacapu population, Zacapu Lake Drainage.

Fig. 2.- A) Yuriria amatlana sp. nov. Holotype CPUM-1630 de la población de Amatlan de Cañas, cuenca del río Ameca. B) Y. chapalae de la presa de Guaracha, cuenca del lago Chapala, y C) Y. alta de la población de Zacapu, Cuenca del Lago Zacapu.

and $Y$. alta. No sexual dimorphism was detected in our analysis. This species is clearly distinguished with respect to its co-distributed related species (Notropis amecae) and other members of the Central Mexico Notropis by having (50-52) 53-54, (mean 52.36, $\mathrm{SD}=1.39$ ) pored lateral-line scales (vs. 11-34 in N. amecae; 1-15 in N. calientis and 39-64 in $N$. sallei) and a complete lateral line (incomplete in the Notropis calientis group and incomplete to complete in $N$. sallei).

DESCRIPTION. D= II-III (7) 8; A= II-III (7) 8; P= I-II (15) 16 (17); $\mathrm{Pv}=\mathrm{II}$ (9) $10 ; \mathrm{C}=(34-35) 36 ; \mathrm{GR}=$ (8) 9 (10), PSL $=(50-52) 53-54, \mathrm{UTS}=10, \mathrm{LST}=5$ (6); pharyngeal teeth 4-4. All morphometric and meristic measurements are shown in Table 2. Like the other species in the genus, Yuriria specimens have two small barbels at the mouth commissure. 
Table 2.- Statistical parameters for the morphometric and meristic characters of Yuriria amatlana sp nov., Y. chapalae and $Y$. alta. Each morphometric variable is divided by standard length. Variable codes are given in the methods section $(\mathrm{SD}=\mathrm{standard}$ deviation).

Tabla 2.- Parámetros estadísticos para los caracteres morfométricos y merísticos de Yuriria amatlana sp. nov., $Y$. chapalae y $Y$. alta. Cada variable morfométrica es dividida por la longitud estándar. Los códigos de las variables se indican en la sección de métodos $(\mathrm{SD}=$ desviación estándar $)$.

\begin{tabular}{|c|c|c|c|c|c|c|c|c|c|}
\hline \multirow{3}{*}{$\begin{array}{l}\text { Species } \\
\text { Population } \\
\text { Morphometrics }\end{array}$} & \multicolumn{3}{|c|}{ Yuriria amatlana sp. nov } & \multirow{2}{*}{\multicolumn{2}{|c|}{$\begin{array}{c}\text { Yuriria chapalae } \\
\text { Guaracha Dam }(n=25) \\
\end{array}$}} & \multicolumn{4}{|c|}{ Yuriria alta } \\
\hline & \multirow[t]{2}{*}{ Holotype } & \multicolumn{2}{|c|}{ Ameca River $(n=30)$} & & & \multicolumn{2}{|c|}{ Zacapu lake $(n=30)$} & \multicolumn{2}{|c|}{ Lajas lake $(n=30)$} \\
\hline & & Range & Mean \pm SD & Range & Mean \pm SD & Range & Mean \pm SD & Range & Mean \pm SD \\
\hline SL (in mm) & 58.66 & $43-92$ & $60.28 \pm 10.5$ & $104-57$ & $86.13 \pm 13.3$ & $161-112$ & $134.8 \pm 14.7$ & $94-47.4$ & $64 \pm 11.6$ \\
\hline HL & 14.36 & $.23-.26$ & $.25 \pm 0.007$ & $.21-.26$ & $.24 \pm 0.01$ & $.24-.28$ & $.26 \pm 0.009$ & $.25-.30$ & $.27 \pm 0.01$ \\
\hline PrOL & 3.53 & $.04-.07$ & $.05 \pm 0.005$ & $.04-.07$ & $.06 \pm 0.008$ & $.05-.09$ & $.07 \pm 0.007$ & $.05-.08$ & $.07 \pm 0.007$ \\
\hline InOW & 3.82 & $.06-.07$ & $.06 \pm 0.003$ & $.04-.06$ & $.05 \pm 0.004$ & $.04-.05$ & $.04 \pm 0.002$ & $.05-.08$ & $.07 \pm 0.008$ \\
\hline PoOL & 7.04 & $.11-.13$ & $.12 \pm 0.006$ & $.11-.14$ & $.13 \pm 0.006$ & $.13-.15$ & $.14 \pm 0.005$ & $.11-.15$ & $.13 \pm 0.008$ \\
\hline $\mathrm{Hh}$ & 9.95 & $.16-.18$ & $.17 \pm 0.005$ & $.14-.23$ & $.16 \pm 0.01$ & $.13-.17$ & $.16 \pm 0.007$ & $.13-.19$ & $.17 \pm 0.01$ \\
\hline $\operatorname{PrP}$ & 15.10 & $.47-.51$ & $.48 \pm 0.008$ & $.24-.48$ & $.27 \pm 0.04$ & $.27-.30$ & $.28 \pm 0.006$ & $.27-.31$ & $.30 \pm 0.01$ \\
\hline $\operatorname{PrD}$ & 28.84 & $.24-.29$ & $.26 \pm 0.01$ & $.47-.51$ & $.48 \pm 0.01$ & $.47-.54$ & $.51 \pm 0.01$ & $.48-.57$ & $.52 \pm 0.01$ \\
\hline PrV & 29.19 & $.49-.51$ & $.50 \pm 0.006$ & $.47-.52$ & $.49 \pm 0.01$ & $.50-.55$ & $.52 \pm 0.01$ & $.49-.56$ & $.53 \pm 0.01$ \\
\hline $\operatorname{PrA}$ & 39.61 & $.66-.72$ & $.69 \pm 0.01$ & $.65-.73$ & $.71 \pm 0.01$ & $.69-.77$ & $.72 \pm 0.01$ & $.69-.77$ & $.72 \pm 0.01$ \\
\hline DFL & 14.04 & $.22-.26$ & $.23 \pm 0.008$ & $.17-.23$ & $.20 \pm 0.01$ & $.16-.22$ & $.19 \pm 0.01$ & $.17-.22$ & $.19 \pm 0.01$ \\
\hline PFL & 12.55 & $.17-.21$ & $.19 \pm 0.01$ & $.22-.27$ & $.24 \pm 0.01$ & $.18-.24$ & $.21 \pm 0.01$ & $.21-.27$ & $.23 \pm 0.01$ \\
\hline PvFL & 9.54 & $.13-.16$ & $.15 \pm 0.006$ & $.14-.18$ & $.17 \pm 0.008$ & $.13-.16$ & $.15 \pm 0.07$ & $.09-.20$ & $.15 \pm 0.01$ \\
\hline AFL & 9.08 & $.14-.19$ & $.16 \pm 0.009$ & $.15-.19$ & $.17 \pm 0.01$ & $.07-.16$ & $.14 \pm 0.01$ & $.13-.21$ & $.16 \pm 0.01$ \\
\hline EALP & 20.12 & $.31-.34$ & $.33 \pm 0.009$ & $.30-.36$ & $.33 \pm 0.01$ & $.26-.33$ & $.30 \pm 0.01$ & $.26-.34$ & $.29 \pm 0.01$ \\
\hline ADUP & 31.43 & $.51-.54$ & $.53 \pm 0.01$ & $.48-.57$ & $.52 \pm 0.01$ & $.20-.57$ & $.51 \pm 0.08$ & $.47-.55$ & $.51 \pm 0.01$ \\
\hline $\mathrm{BD}$ & 13.23 & $.20-.23$ & $.22 \pm 0.007$ & $.22-.29$ & $.25 \pm 0.01$ & $.26-.31$ & $.29 \pm 0.01$ & $.24-.27$ & $.25 \pm 0.009$ \\
\hline BLD & 6.52 & $.10-.11$ & $.11 \pm 0.004$ & $.10-.14$ & $.12 \pm 0.08$ & $.10-.12$ & $.11 \pm 0.004$ & $.10-.12$ & $.11 \pm 0.005$ \\
\hline DAOD & 17.19 & $.27-.31$ & $.29 \pm 0.01$ & $.29-.35$ & $.31 \pm 0.01$ & $.27-.35$ & $.32 \pm 0.01$ & $.28-.32$ & $.30 \pm 0.009$ \\
\hline \multicolumn{10}{|l|}{ Meristics } \\
\hline $\mathrm{D}$ & 7 & $7-8$ & $7.03 \pm 0.18$ & $7-8$ & $7.04 \pm 0.20$ & $6-7$ & $6.96 \pm 0.18$ & $6-7$ & $6.96 \pm 0.18$ \\
\hline $\mathrm{Pv}$ & 9 & $9-10$ & $9.36 \pm 0.49$ & $8-11$ & $9.68 \pm 0.86$ & $7-8$ & $7.96 \pm 0.18$ & $7-8$ & $7.96 \pm 0.18$ \\
\hline A & 7 & $7-8$ & $7.06 \pm 0.25$ & $7-8$ & $7.64 \pm 0.48$ & $6-8$ & $6.96 \pm 0.32$ & $6-7$ & $6.93 \pm 0.25$ \\
\hline PLS & 53 & $50-54$ & $52.36 \pm 1.39$ & $48-51$ & $50.20 \pm 0.95$ & $47-51$ & $50.10 \pm 1.06$ & $47-51$ & $48.73 \pm 1.29$ \\
\hline UTS & 10 & 10 & 10 & $8-9$ & $8.68 \pm 0.41$ & $8-9$ & $8.94 \pm 0.21$ & $8-9$ & $8.94 \pm 0.24$ \\
\hline LTS & 5 & $5-6$ & $5.23 \pm 0.33$ & $5-6$ & $5.23 \pm 0.43$ & 5 & 5 & $5-6$ & $5.08 \pm 0.14$ \\
\hline GR & 9 & $8-10$ & $8.86 \pm 0.57$ & $7-9$ & $8.28 \pm 0.59$ & $7-8$ & $7.08 \pm 0.28$ & $7-9$ & $7.6 \pm 0.66$ \\
\hline
\end{tabular}

The body is moderately deep, laterally compressed and elongated. Its maximum height is 4.09-4.81 (mean $=4.4)$ times the standard length and minimum body height 8.15-9.84 $($ mean $=8.9)$ times the standard length. Ventral and dorsal profile moderately arched in the anterior half of the body. The mouth is protractile, terminal and oblique. Snout slightly rounded, preorbital distance 14.83-18.30 (mean = 16.9) times the standard length. Head longer than high and moderately pointed, cephalic length 3.6-4.2 (mean $=3.9)$ times the standard length and cephalic height 5.44-6.35 $($ mean $=5.8)$ times the standard length. The scales are large and not tightly imbrica- ted. Lateral line completed and strongly curved in the pectoral fin region. The dorsal and anal fins are short, dorsal fin is 3.78-4.8 (mean $=4.2$ ) times the standard length and anal fin is 5.22-6.87 (mean = 5.9) times the standard length. The pelvic fin arises at or slightly behind the origin of the dorsal fin, predorsal distance is 1.9-2.11 (mean $=2.0)$ times the standard length and preventral distance 1.8-2.09 $($ mean $=1.9)$ times the standard length. Caudal fin deeply forked. The caudal peduncle is long, anal peduncle distance 2.86-3.34 $($ mean $=3.0)$ times the standard length and dorsal peduncle distance 1.81$1.98($ mean $=1.8)$ times the standard length. 
Table 3.- Summary of the diagnostic characters of the populations of Yuriria spp. In brackets number of individuals analyzed.

Tabla 3.- Resumen de los caracteres diagnósticos de las poblaciones de Yuriria spp. Entre paréntesis el número de individuos analizados.

\begin{tabular}{lccc}
\hline Characters & Yuriria amatlana sp. nov. & Yuriria chapalae & Yuriria alta \\
\hline Number of pored scales in a lateral series & $50(4)-51(5)-52(5)-53(8)-54(8)$ & $48(1)-49(6)-50(5)-51(13)$ & $47(7)-48(9)-49(12)-50(20)-51(12)$ \\
Number of scales in transverse series & $16(5)-17(13)-18(12)$ & $13(1)-14(11)-15(13)$ & $14(4)-15(55)-16(1)$ \\
Pelvic fin branched rays & $9(19)-10(11)$ & $8(3)-9(5)-10(14)-11(3)$ & $7(2)-8(58)$ \\
Anal fin branched rays & $7(28)-8(2)$ & $7(9)-8(16)$ & $6(3)-8(1)-7(56)$ \\
Gill rakers & $8(8)-9(20)-10(2)$ & $7(5)-8(8)-9(12)$ & $7(25)-6(34)-9(1)$ \\
Body colour & Light yellow-cream & Reddish-yellow & Dark brown \\
\hline
\end{tabular}

PigmentATION PATTERn. The body color of preserved specimens is light yellowish-brown. Individuals show a dark lateral stripe, more conspicuous and broad in the postdorsal region of the body, and less apparent and more diffuse in the predorsal region. Yuriria amatlana sp. nov. has a dark patch in the caudal peduncle at the end of the lateral stripe in the hypural region. The base of the dorsal fin shows fine pigment stripes and most of the specimens analysed have dark spots in the dorsal region. Snout and upper part of the head pigmented. All fins clear and unpigmented.

ETymology. The name "amatlana" was taken from the name of the region of the type locality, Amatlan de Cañas.

DisTRIBUTION AND HABITAT. The type locality of Y. amatlana sp. nov. is the Río Chiquito, near Ixtlan del Río in the Ameca river drainage, approximately $6 \mathrm{~km}$ south of the town of Amatlan de Cañas, in the state of Nayarit. The taxon is only known in the Ameca basin. The presence of Yuriria in the Ameca basin has been reported in the Teuchitlan River, Atenguillo river, Ameca river near the town of Ameca and in Ahuacatlan, all in the state of Jalisco, western Central Mexico (Miller \& Smith, 1986; Espinosa et al., 1993; Miller et al., 2005; University of Michigan Museum of Zoology and CPUM fish-database) (Fig. 1). At its type locality, the river is $10 \mathrm{~m}$ wide on average and depth is $1 \mathrm{~m}$ average. The substrate is principally sand and gravel, with a considerable number of boulders on the river bed. Riparian vegetation is a gallery forest composed mainly of Taxodium sp., with roots penetrating the river bank. When the river was sampled in the rainy season, the water was a turbid brown colour with high amounts of suspended material.
Water temperature was $22^{\circ} \mathrm{C}$. Water flow is rapid with some meanders showing moderate flow. Aquatic vegetation was poor at the time of sampling, possibly because of swelling of the river. Fish were captured in the fast flow areas of the river. Associated native fish fauna were Xenotoca melanosoma Fitzsimons, 1972, Goodea atripinnis Jordan, 1880, Ilyodon furcidens (Jordan \& Gilbert, 1882), Ictalurus sp., Agonostomus monticola (Bancroft, 1834) and Scartomyzon austrinus (Bean, 1880), along with the introduced Cyprinus carpio Güldenstädt, 1772 and Oreochromis sp.

CONSERVATION STATUS. The species is known from only a few sites within the Ameca River system, and now can be found only in the headwaters of the Ameca river. Although the sampling effort made in its distribution area has been intense, in the last three years no specimens of Yuriria amatlana sp. nov. have been collected at five of the six historical sites which were previously reported, representing more than $85 \%$ of extinction in previously known populations (Fig. 2). The sites where the species has recently disappeared have been mostly affected by the introduction of exotic species, water pollution and the use of water for agricultural or recreational purposes. According to the criteria and categories of the International Union for the Conservation of Nature and Natural Resources (IUCN, 2001 - http://app.iucn. org/webfiles/doc/SSC/RedList/RedListGuidelines. pdf), this species should be considered critically endangered (A 2a,c,e).

\section{Comparative data and Discussion}

The results of our meristic and morphometric analysis of specimens of $Y$. amatlana sp nov. $(n=$ 
Table 4.- Molecular diagnostic characters for the cytochrome $b$ gene in the genus Yuriria. Ts $=$ transition and Tv= transversion within the same base position.

Tabla 4.- Caracteres moleculares diagnósticos para el gen citocromo $b$ en el género Yuriria. Ts $=$ transición y Tv= transversión dentro de las mismas posiciones.

\begin{tabular}{|c|c|c|c|c|c|c|c|c|c|c|c|c|c|c|c|c|c|c|c|c|c|c|c|c|c|}
\hline $\begin{array}{l}\text { BP positio } \\
\text { Species }\end{array}$ & 36 & 45 & 108 & 115 & 141 & 174 & 282 & 294 & 3483 & 351 & 354 & 366 & 375 & 408 & 423 & 444 & 459 & 462 & 498 & 537 & 56157 & $79 \quad 580$ & 591 & 609 & 654 \\
\hline Y. alta & $\mathrm{G}$ & $\mathrm{C}$ & G & $\mathrm{C}$ & $\mathrm{C}$ & $\mathrm{C}$ & $\mathrm{C}$ & $\mathrm{T}$ & $\mathrm{G}$ & A & $\mathrm{C}$ & $\mathrm{G}$ & $\mathrm{A}$ & $\mathrm{T}$ & A & $\mathrm{T}$ & $\mathrm{G}$ & $\mathrm{T}$ & A & $\mathrm{C}$ & $\mathrm{C} \quad \mathrm{C}$ & $\mathrm{G}$ & A & $\mathrm{A}$ & $\mathrm{T}$ \\
\hline Y. chapalae & A & $\mathrm{C}$ & A & $\mathrm{C}$ & $\mathrm{T}$ & $\mathrm{T}$ & $\mathrm{C}$ & $\mathrm{T}$ & G & G & $\mathrm{C}$ & A & A & $\mathrm{T}$ & G & $\mathrm{C}$ & $\mathrm{G}$ & $\mathrm{C}$ & $\mathrm{T}$ & $\mathrm{C}$ & $\mathrm{T} \quad \mathrm{C}$ & A & A & A & $\mathrm{T}$ \\
\hline Y. amatlana & G & $\mathbf{T}$ & G & $\mathbf{T}$ & $\mathrm{C}$ & $\mathrm{C}$ & $\mathbf{T}$ & $\mathrm{C}$ & $\mathbf{A}$ & A & $\mathbf{T}$ & A & $\mathbf{T}$ & C & A & $\mathrm{T}$ & C & $\mathrm{T}$ & A & $\mathbf{T}$ & $\mathrm{C}$ & $\mathrm{G}$ & G & G & $\mathrm{C}$ \\
\hline Substitution type & Ts & Ts & Ts & Ts & Ts & Ts & Ts & Ts & Ts & Ts & Ts & Ts & $\mathrm{Tv}$ & Ts & Ts & Ts & $\mathrm{Tv}$ & Ts & $\mathrm{Tv}$ & Ts & Ts Ts & Ts & Ts & Ts & Ts \\
\hline D. & & & & & & & & & & & & & & & & & & & & & & & & & \\
\hline Species & 699 & 703 & 705 & 714 & 732 & 777 & 801 & 810 & 813 & 816 & 849 & 867 & 906 & 918 & 919 & 930 & 966 & 972 & 984 & 1003 & 31017 & 1050 & 1077 & 1131 & \\
\hline Y. alta & $\mathrm{C}$ & A & G & G & A & A & $\mathrm{T}$ & $\mathrm{C}$ & G & A & $\mathrm{C}$ & A & A & $\mathrm{T}$ & $\mathrm{C}$ & $\mathrm{T}$ & A & G & A & $\mathrm{C}$ & $\mathrm{G}$ & $\mathrm{T}$ & $\mathrm{T}$ & $\mathrm{G}$ & \\
\hline Y. chapalae & $\mathrm{C}$ & G & G & G & A & $\mathrm{G}$ & $\mathrm{T}$ & $\mathrm{T}$ & A & $\mathrm{G}$ & $\mathrm{C}$ & A & A & $\mathrm{T}$ & $\mathrm{C}$ & A & A & $\mathrm{G}$ & G & $\mathrm{C}$ & A & $\mathrm{T}$ & $\mathrm{T}$ & $\mathrm{A}$ & \\
\hline Y. amatlana & $\mathbf{T}$ & A & $\mathbf{A}$ & $\mathbf{A}$ & $\mathbf{G}$ & A & $\mathbf{C}$ & $\mathrm{C}$ & A & A & $\mathbf{T}$ & $\mathbf{G}$ & $\mathbf{G}$ & C & $\mathbf{T}$ & A & G & $\mathbf{A}$ & A & $\mathbf{T}$ & A & $\mathbf{C}$ & $\mathbf{C}$ & G & \\
\hline Substitution type & Ts & Ts & Ts & Ts & Ts & Ts & Ts & Ts & Ts & Ts & Ts & Ts & Ts & Ts & Ts & $\mathrm{Tv}$ & Ts & Ts & Ts & Ts & Ts & Ts & Ts & Ts & \\
\hline
\end{tabular}

30), $Y$. chapalae $(n=25)$ and $Y$. alta $(n=60)$, are provided in Table 2 and Figure 3.

\section{MORPHOMETRICS}

As discussed above, specimens of the genus Yuriria from the Ameca river basin show many diagnostic meristic and genetic differences with respect to their two sister species Y. alta and Y. chapalae, and therefore warrant designation as a new species, Yuriria amatlana sp. nov.

In an exploratory PCA including morphometric measurements, PCI explained $93.29 \%$ of the variation and eigenvectors showed closed values with the same symbol, suggesting the influence of standard length on the results (Bookstein et al., 1985; Doadrio et al., 2002). A second PCA conducted with a Burnaby corrected matrix, revealed $51 \%$ of variance in PCI and a cumulative $63.84 \%$ in PCII. The characters found to contribute most to variation were interorbital width, head height and the distance from the snout to the base of the ventral fin and pectoral fin in PCI, and body depth in PCII (Table 5). The variation pattern was more influenced by PCI (Fig. 3A) and the most differentiated population was that from the $\mathrm{La}$ Laja River. No well-defined groups emerged, and no evident morphological diagnostic characters appeared among the three species (Y. alta, Y. cha- palae and Y. amatlana) (Fig. 3A). Despite morphology having been largely used as the basis for species descriptions, many species show a high degree of phenotypic plasticity depending on habitat conditions, and the influence of allometry in morphometric measurements has been widely recognized (Hood \& Heins, 2000; Trapani et al., 2005). We conclude that morphologic measurements alone are not appropriate diagnostic characters for the identification of Yuriria species. Thus, other sources of information such as the biogeographic, meristic, pigmentation patterns and molecular data are used here for species recognition. In our PCA analyses based on meristic characters, PCI explained $41.62 \%$ of variance and PCI + PCII explained a cummulative $63.17 \%$ of the variance. Moreover, high eigenvector values were associated with the characters branched rays on pelvic fin, number of pored scales in the lateral series and gill rakers in PCI, separating the two populations of $Y$. alta with respect to $Y$. chapalae and $Y$. amatlana, and anal fin rays and scales in a transverse series in PCII, separating $Y$. chapalae from $Y$. amatlana (Table 6). For the meristic characters, the analysis indicated a variation pattern with the formation of three well-defined groups, with practically no overlap among ellipses (Fig. 3B). 

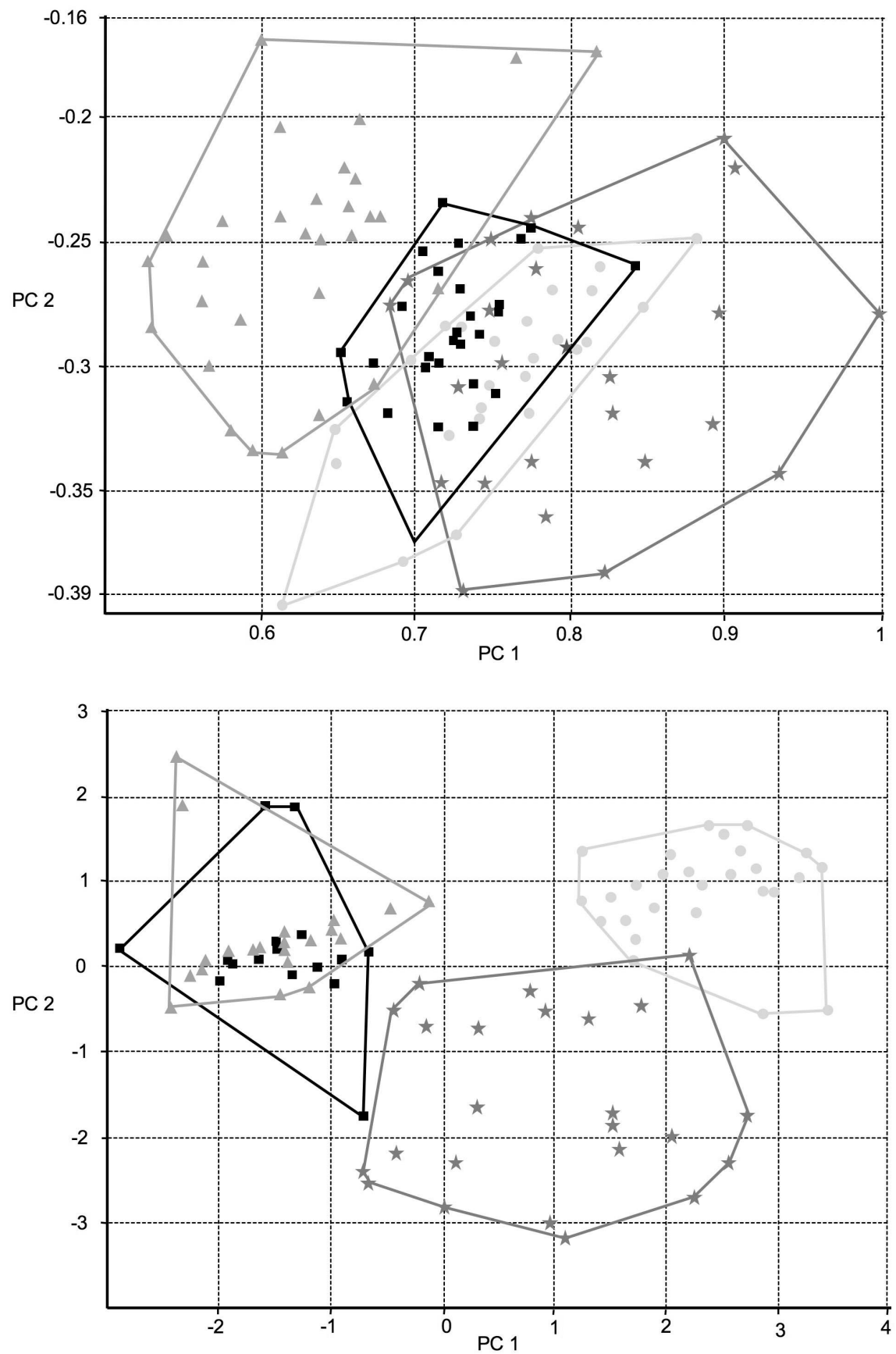

Fig. 3.- A) Plots of the first two principal components for 19 Burnaby-corrected morphometric variables. B) Plots of the first two principal components for 7 meristic variables. Triangles correspond to $Y$. alta from the Laja River population (Middle Lerma Basin); squares to Y. alta from the Zacapu populations (Zacapu Lake Basin); stars to the Y. chapalae population from Guaracha Dam (Chapala Lake Basin); and circles to Y. amatlana sp. nov. from the Amatlan de Cañas population (Ameca River Basin).

Fig. 3.- A) Gráficos de los primeros dos componentes principales para 19 variables morfométricas Burnaby-corregidas. B) Gráficos de los dos primeros componentes principales para 7 variables merísticas. Triángulos corresponden a $Y$. alta de la población del río Laja (Cuenca media del Lerma); cuadrados a $Y$. alta de la población de Zacapu (Cuenca del Lago Zacapu); estrellas a Y. chapalae de la población de la presa de Guaracha (Cuenca del Lago de Chapala); y círculos a Y. amatlana sp. nov. de la población de Amatlan de Cañas (Cuenca del río Ameca). 
Table 5.- Eigenvectors and eigenvalues for the first four principal components obtained for 19 morphometric variables. Variable codes are given in the methods section.

Tabla 5.- Eigenvectores y eigenvalores para los cuatro primeros componentes principales obtenidos para 19 variables morométricas. Los códigos de las variables se explican en la sección de métodos.

\begin{tabular}{lcccc}
\hline Variable/eigenvectors & PCI & PCII & PCIII & PCIV \\
\hline SL & 0.040 & 0.003 & 0.041 & 0.001 \\
HL & 0.016 & -0.020 & 0.035 & 0.000 \\
PrOL & -0.111 & 0.026 & 0.078 & -0.003 \\
InOW & 0.156 & -0.143 & -0.011 & -0.004 \\
PoOL & 0.053 & 0.007 & 0.053 & 0.004 \\
Hh & 0.153 & -0.012 & -0.056 & 0.010 \\
PrP & 0.062 & 0.080 & -0.020 & 0.008 \\
PrD & 0.088 & 0.000 & 0.035 & 0.002 \\
PrV & 0.147 & -0.020 & -0.001 & 0.003 \\
PrA & 0.124 & -0.009 & 0.026 & 0.003 \\
DFL & -0.036 & -0.049 & -0.017 & 0.001 \\
PFL & -0.227 & -0.149 & -0.097 & 0.003 \\
PvFL & -0.022 & -0.058 & 0.007 & 0.000 \\
AFL & -0.052 & -0.082 & 0.086 & 0.007 \\
EALP & -0.117 & 0.022 & 0.091 & 0.000 \\
ADUP & 0.023 & 0.018 & -0.020 & -0.050 \\
BD & -0.027 & 0.107 & -0.076 & 0.004 \\
BLD & -0.135 & 0.081 & -0.010 & 0.006 \\
DAOD & 0.015 & 0.036 & -0.077 & 0.005 \\
\hline Eigenvalues & 0.0082 & 0.0020 & 0.0015 & 0.0009 \\
Percentage & 51.00 & 12.84 & 9.62 & 5.81 \\
Cumulative \% & 51 & 63.84 & 73.46 & 79.27 \\
\hline & & & &
\end{tabular}

\section{GENETICS}

We found 53 variable characters, of which 45 were parsimony informative. Third codon positions were the most informative characters (29 informative characters), followed by first codon positions (15 characters). Saturation of transition and transversion changes was checked by plotting the absolute number of changes of each codon position against patristic distances. There was no ingroup evidence of saturation at any of the three positions (data not shown). The HKY model was selected as the model best fitting the data set. Rate matrix parameters were: $-\operatorname{lnL}=2087.9932 ; \mathrm{K}=4$; $\mathrm{BIC}=$ 4204.1450. Base frequencies were: freq $\mathrm{A}=0.2704$; freq $\mathrm{C}=0.2776$; freqG $=0.1653$; freq $\mathrm{T}=0.2868$. Among-site rate variation was equal. For the Bayesian phylogenetic analysis, $5 \%$ of the generations obtained were burnt and discarded. The con-
Table 6.- Eigenvectors and eigenvalues for the first three principal components obtained for 6 meristic variables. Variable codes are given in the methods section.

Tabla 6.- Eigenvectores y eigenvalores para los tres primeros componentes principales obtenidos para 6 variables merísticas. Los códigos de las variables se explican en la sección de métodos.

\begin{tabular}{lccc}
\hline Variable/eigenvectors & PCI & PCII & PCIII \\
\hline PSL & 0.4934 & 0.0854 & -0.3719 \\
D & 0.1346 & 0.0627 & 0.8836 \\
Pv & 0.5239 & -0.35 & 0.080 \\
A & 0.1794 & -0.8015 & -0.0512 \\
UTS & 0.4472 & 0.448 & -0.1604 \\
LTS & 0.1046 & 0.0427 & 0.3836 \\
GR & 0.4815 & 0.1612 & 0.2149 \\
\hline Eigenvalues & 2.40 & 1.24 & 0.82 \\
Percentage & 41.62 & 21.55 & 14.25 \\
Cumulative \% & 41.62 & 63.17 & 74.21 \\
\hline
\end{tabular}

sensus tree revealed three main clades in the genus Yuriria, with high Bayesian posterior probabilities (BPP) obtained: one formed by Y. alta populations (BPP 96), another by the only population of Y. chapalae (100 BPP) and a last clade by the new taxon Y. amatlana (100 BPP) (see Fig. 4). Genetic distances were: ${ }^{\prime} \mathrm{D}_{\mathrm{HKY}}=3.8 \%$ (range $3.2 \%$ to $4.4 \%$ ) between $Y$. alta and $Y$. amatlana; $\mathrm{D}_{\mathrm{HKY}}=5 \%$ (range $4.8 \%$ to $5.2 \%$ ) between $Y$. amatlana and $Y$. chapalae; and ${ }^{\prime} \mathrm{D}_{\mathrm{HKY}}=2.6 \%$ (range $2.1 \%$ to $3.3 \%$ ) between $Y$. chapalae and $Y$. alta. Pairwise genetic distances between the populations analysed are shown in table 7.

Meristic and molecular data are congruent in recognizing three well differentiated groups corresponding to the two described species ( $Y$. alta and $Y$. chapalae) and the new taxon (Y. amatlana). Based on these characters, we confirmed our meristic data indicating the existence of a new Yuriria genus taxon in the Ameca river basin. Assuming a molecular clock of 1 million years per 1\% pairwise differences, which is the generally accepted rate for the cytochrome $b$ gene in other cyprinids, including Notropis species from Central Mexico (Dowling et al., 2002; Shönhunth, 2002; Doadrio \& Carmona, 2004), the Yuriria species from the Ameca river diverged from the other species of Yuriria in contiguous basins during the Pliocene, approximately 3.8 Mya. These results are consistent with findings for other pairs of sister species inhabiting the 


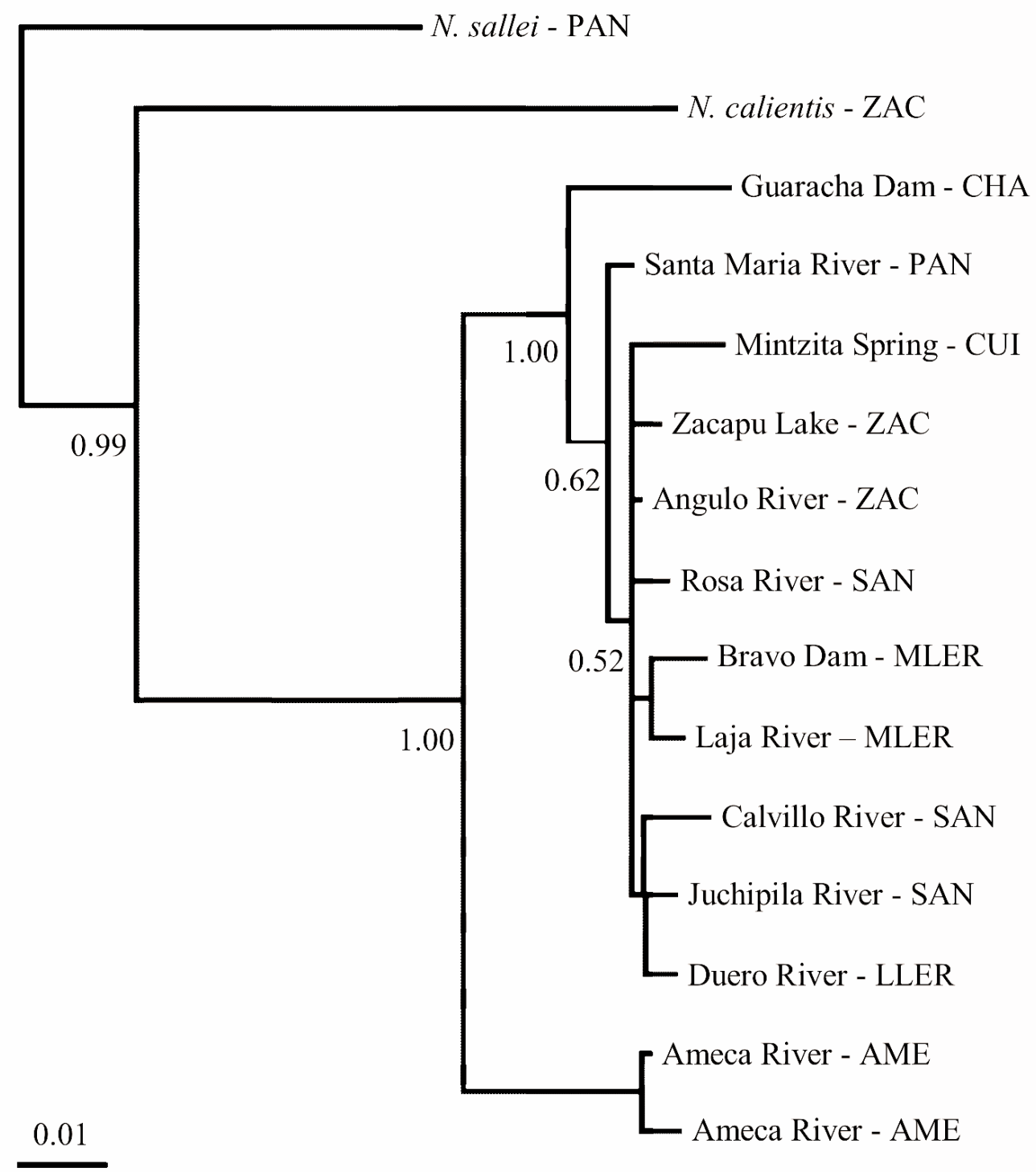

Fig. 4.- Phylogenetic tree for 12 specimens of the genus Yuriria recovered from cytochrome $b$ sequences (1140 bp) according to a Bayesian analysis based on HKY model. Numbers below the branches indicate Bayesian posterior probabilities.

Fig. 4.- Árbol filogenético para 12 individuos del género Yuriria con secuencias del citocromo $b$ (1140 bp) de acuerdo al análisis bayesiano con el HKY modelo. Número debajo de las ramas indican valores de probabilidades posteriores.

Ameca river basin and other drainages of Central Mexico (e.g., cladogenesis of Allotoca goslinae Smith \& Miller, 1987 and Ameca splendens Miller \& Fitzsimons, 1971, with an estimated divergence time of 3.7 Mya, sensu Doadrio \& DomínguezDomínguez, 2004). These data confirm an ancestral connection between the Ameca and contiguous basins and could suggest the cladogenetic event was induced by the same vicariant event promoted by tectonic activity during that period (see Domínguez-Domínguez et al., 2006). Given the disappearance of many of its historical occurrence points, its degraded habitat and the extinction of other species in the basin, we recommend that Yuriria amatlana be added to the current list of endangered species. 
Table 7.- Percentage of divergences (above the diagonal) and pairwise genetic distances (below the diagonal) among Yuriria amatlana, Y. chapalae and Y. alta populations obtained using the HKY model.

Tabla 7.- Porcentaje de divergencia (encima de la diagonal) y distancias genéticas pareadas (debajo de la diagonal) entre poblaciones de Yuriria amatlana, Y. chapalae y Y. alta usando el modelo HKY.

\begin{tabular}{|c|c|c|c|c|c|c|c|c|c|c|c|c|}
\hline Species & Populations & Mintzita & Bravo & Laja & Zacapu & Angulo & Rosa & Calvillo & Juchipila & Duero & Guaracha & Ameca \\
\hline \multirow[t]{9}{*}{ Yuriria alta } & Mintzita & & 1.5 & 1.42 & 1.32 & 1.06 & 1.42 & 1.86 & 1.5 & 1.5 & 3.34 & 4.19 \\
\hline & Bravo & 0.015 & & 0.79 & 0.88 & 0.79 & 1.06 & 1.49 & 1.06 & 1 & 2.87 & 4.29 \\
\hline & Laja & 0.0142 & 0.0079 & & 0.61 & 0.52 & 0.7 & 1.21 & 0.79 & 0.79 & 2.6 & 4 \\
\hline & Zacapu & 0.0132 & 0.0088 & 0.0061 & & 0.26 & 0.7 & 1.02 & 0.7 & 0.7 & 2.51 & 3.72 \\
\hline & Angulo & 0.0106 & 0.0079 & 0.0052 & 0.0026 & & 0.44 & 0.74 & 0.44 & 0.44 & 2.23 & 3.44 \\
\hline & Rosa & 0.0142 & 0.0106 & 0.007 & 0.007 & 0.0044 & & 1.12 & 0.7 & 0.7 & 2.42 & 3.92 \\
\hline & Calvillo & 0.0186 & 0.0149 & 0.0121 & 0.0102 & 0.0074 & 0.0112 & & 0.93 & 0.83 & 2.94 & 4.24 \\
\hline & Juchipila & 0.015 & 0.0106 & 0.0079 & 0.007 & 0.0044 & 0.007 & 0.0093 & & 0.52 & 2.51 & 3.91 \\
\hline & Duero & 0.015 & 0.01 & 0.0079 & 0.007 & 0.0044 & 0.007 & 0.0083 & 0.0052 & & 2.51 & 3.95 \\
\hline Y. chapalae & Guaracha & 0.0334 & 0.0287 & 0.026 & 0.0251 & 0.0223 & 0.0242 & 0.0294 & 0.0251 & 0.0251 & & 5.06 \\
\hline Y. amatlana & Ameca & 0.0419 & 0.0429 & .0400 & 0.0372 & 0.0344 & 0.0392 & 0.0424 & 0.0391 & 0.0395 & 0.0506 & \\
\hline
\end{tabular}

\section{ACKNOWLEDGMENTS}

The authors thank Rodolfo Pérez, Luis Escalera and Rogelio Rosas for their help during field trips and Lourdes Alcaraz and Carlos Pedraza for their help with the laboratory work. Thanks also to Carlos Escalera from CIDIR-Jiquilpan for providing samples from $Y$. chapalae (Guaracha Dam). Ana Burton for the revision of the original version of this manuscript. OD was funded by the Chester Zoo Garden, England. We are indebted to Ivan Dibble for his support from the Hobbyist Aqualab Conservation Project (HALCP) that receives funds from European and North American aquarist associations. OD was awarded a scholarship by the Consejo Nacional de Ciencia y Tecnología.

\section{References}

Bookstein, F. B., Chernoff, B., Elder, R. L., Humphries, J. M., SMIth, G. \& Strauss, G., 1985. Morphometrics in Evolutionary Biology. Academy of Natural Sciences of Philadelphia. Special Publication, 15: 1-277.

BURNABY, T. P., 1966. Growth-invariant discriminant functions and generalized distances. Biometrics, 22: 96-110.

Chernoff, B. \& Miller, R. R., 1986. Fishes of the Notropis calientis complex with a key to the Southern Shiners of Mexico. Copeia, 1986(1): 170-183.

Coburn, M. M. \& CAVEnder, T. M., 1992. Interrelationships of North American cyprinid fishes. In: R. L. Mayden (ed.). Systematics, historical ecology, and North American freshwater fishes. Stanford University Press. Stanford: 328-373.

DoAdrio, I. \& CARMONA, J. A., 2004. Phylogenetic relationships and biogeography of the genus Chondrostoma inferred from mitochondrial DNA sequences. Molecular Phylogenetics and Evolution, 33: 802-815.

DoAdrio, I., CARmona, J. A. \& Fernández-Delgado, C., 2002. Morphometric study of the Iberian Aphanius (Actinopterygii, Cyprinodontiformes), with description of a new species. Folia Zoologica, 51: 67-79.

DoAdrio, I. \& Domínguez-Domínguez, O., 2004. Phylogenetic relationships within the fish family Goodeidae based on cytochrome b sequence data. Molecular Phylogenetics and Evolution, 31: 416-430.

Domínguez-Domínguez, O., DoAdrio, I. \& Pérez-Ponce DE LEÓN, G., 2006. Historical biogeography of some river basins in Central Mexico evidenced by their goodeine freshwater fishes: A preliminary hypothesis using secondary Brooks Parsimony Analysis (BPA). Journal of Biogeography, 33: 1437-1447.

Dowling, T. E., Tibbets, C. A., Minckley, W. L. \& SMith, G. R., 2002. Evolutionary relationships of the plagopterins (Teleostei: Cyprinidae) from Cytochrome b sequences. Copeia, 2002(3): 655-678.

Espinosa Pérez, H., Gaspar Dillanes, M. T. \& Fuentes MatA, P., 1993. Listados faunísticos de México. III. Los peces dulceacuícolas mexicanos. Instituto de Biología, Universidad Nacional Autónoma de México. México D.F. 98 pp.

GiLBert, C. R., 1998. Type catalog of Recent and fossil North American Freshwater fishes: families Cyprinidae, Catostomidae, Ictaluridae, Centrarchidae and Elassomatidae. Florida Museum of Natural History, Special Publication, 1: 1-284.

Hood, C. S. \& HeINS, D. C., 2000. Ontogeny and Allometry of Body Shape in the Blacktail Shiner, Cyprinella venusta. Copeia, 2000(1): 270-275. 
Hueselsenbeck, J. P. \& RonQuist, F. R., 2001. MrBayes: Bayesian inference of phylogeny. Bioinformatics, 17: 754-755.

Humphries, J. M., Bookstein, F. L., Chernoff, B., Smith, G. R., Elder, R. L. \& Poss, S. G., 1981. Multivariate discrimination by shape in relation to size. Systematic Zoology, 30: 291-308.

Jolicoeur, P. \& Mosimann, J. E., 1960. Size and shape variation in the painted turtle. A principal component analysis. Growth, 24: 339-354.

Lyons, J., González-Hernández, G., Soto-Galera, E. \& GuZMÁN-Arroyo, M., 1998. Decline of fishes and fisheries in selected drainages of west-central Mexico. Fisheries, 23: 10-18.

Lyons, J., Gutiérrez-Hernández, A., Díaz-Pardo, E., Soto-Galera, E., Medina-Nava, M. \& PinedALÓPEZ, R., 2000. Development of a preliminary index of biotic integrity (IBI) based on fish assemblages to assess ecosystem condition in the lakes of central Mexico. Hidrobiologia, 418: 57-72.

Mayden, R. L., 1989. Phylogenetics studies of North American minnows, with emphasis on the genus Cyprinella (Teleostei: Cypriniformes). Miscellaneous Publications, The University of Kansas Museum of Natural History, 80: 1-189.

Mayden, R. L., 1991. Cyprinids of the new world. In: I. J. Winfield \& J. S. Nelson (eds.). Cyprinid fishes: systematics, biology and exploitation. Chapman \& Hall. London: 240-263.

Mercado-Silva, N., Lyons, J., Salgado, M. G. \& MEdinA, N. M., 2002. Validation of a fish-based index of biotic integrity for streams and rivers of central Mexico. Reviews in Fish Biology and Fisheries, 12: 179-191.

Miller, R. R., Minckley, W. L. \& Norris, S. M., 2005. Freshwater fishes of México. The University of Chicago Press. Chicago. 490 pp.

Miller, R. R. \& SMith, M. L., 1986. Origin and geography of the fishes of central Mexico. In: C. C. H. Hocutt \& E. O. Wiley (eds.). The zoogeography of North American freshwater fishes. Wiley-Interscience Publications. New York: 487-519.

Posada, D. \& Crandall, K. A., 1998. Modeltest: testing the model of DNA substitution. Bioinformatics, 14: $817-818$.

RoHFL, F. J., 2000. NTSYS-pc: Numerical taxonomy and multivariate analysis system, version 2.1. Setauket. New York.
Rohfl, F. J. \& Bookstein, F. L., 1987. A comment on shearing as a method for size correction. Systematic Zoology, 36: 356-367.

Sambrook, J., Fritsch, E. F. \& Maniatis, T., 1989. Molecular Cloning: A Laboratory Manual. Cold Spring Harbor Laboratory. New York. 746 pp.

SCHÖNHUTH, M. S., 2002. Sistemática, filogenia e implicaciones biogeográficas de las poblaciones del género Notropis Rafinesque, 1817 (Actinopterygii: Cyprinidae) en el centro y sur de México. Tesis Doctoral, Universidad Complutense de Madrid. 157 pp.

SchÖNhuth, M. S. \& DoAdrio, I., 2003. Phylogenetic relationships of Mexican minnows of the genus Notropis (Actinopterygii, Cyprinidae). Biological Journal of the Linnean Society, 80: 323-337.

SwOFFord, D. L., 1998. PAUP*. Phylogenetic analysis using parsimony (*and other methods). Sinauer Associates. Sunderland.

Trapani, J., Yamamoto, Y. \& Stock, D. W., 2005. Ontogenetic transition from unicuspid to multicuspid oral dentition in teleost fish: Astyanax mexicanus, the Mexican tetra (Ostariophysi: Characidae). Zoological Journal of the Linnean Society, 145: 523-538.

UyenO, T., 1961. Osteology and phylogeny of the American cyprinid fishes allied to the genus Gila. Unpublished $\mathrm{PhD}$ Dissertation. University of Michigan. 245 pp.

ZARDOYA, R. \& DoAdrio, I., 1998. Phylogenetic relationships of Iberian cyprinids: systematic and biogeographical implications. Proceedings of the Royal Society of London, 265: 1365-1372.
Recibido, 13-II-2007

Aceptado, 5-VII-2007 Publicado, 27-XII-2007 